\title{
LITERACKA ANTROPOLOGIA SZKOŁY PRZEŁOMU XIX I XX W. REKONESANS
}

\author{
MARTA RUSEK*
}

\section{WYJAŚNIENIE PIERWSZE - ANTROPOLOGIA SZKOŁY I LITERATURA}

„Bogowie nigdy nie mają uczniów i nie tworzą szkół” - zanotował w 1902 roku Aleksander Świętochowski. Aforystyczna myśl - działając jak negatyw - odsłania oczywisty, ale poprzez swoją oczywistość często niedoceniany fakt, że zinstytucjonalizowane uczenie się i nauczanie jest praktyką swoiście ludzką. Wynika ona z właściwej człowiekowi epistemologicznej potrzeby, dotyczącej rozpoznawania, rozumienia, badania otaczającego świata oraz przekształcania go. Owoce owych poznawczych i adaptacyjnych działań przekazywane są w edukacyjnym procesie przez starsze pokolenia młodszym generacjom, by przygotować je do życia w przyszłości ${ }^{2}$. A zatem zinstytucjonalizowane nauczanie, które mnie interesuje, wpisuje się w historię ludzi oraz rozwój ich cywilizacji, określa kondycję człowieka w jego kulturowej i historycznej zmienności. Zadaniem pedagogicznej antropologii, jak to sformułowała Krystyna Ablewicz, ,jest odsłanianie, a może nawet demaskowanie koncepcji człowieka [podkreśl. - M. R.], które ukrywają się za wszelkimi tendencjami, codziennymi stereotypami instytucji szkoły, życia rodzinnego, całego świata makrospołecznego, za powszechnymi »oczywistościami« czy też edukacyjnymi reformami oraz ich wychowawczymi deklaracjami, które tak naprawdę nimi kierują"3.

* Marta Rusek - dr, Wydział Polonistyki UJ.

${ }^{1}$ A. Ś wię to ch ow ski, Aforyzmy, wybór i wstęp M. Brykalska, Warszawa 1979, s. 45. Odwołuję się do tej sentencji także w artykule „Uksztatcić człowieka” - Aleksandra Świętochowskiego poglądy na edukację... [w:] Aleksander Świętochowski, red. K. Stępnik, M. Gabryś, Lublin 2011, s. 85-94.

${ }^{2} \mathrm{O}$ kierunku kulturowej transmisji, zmianach związanych z przerwaniem ciągłości doświadczenia kulturowego, por. M. Me ad, Kultura i tożsamość. Studium dystansu międzypokoleniowego, przeł. J. Hołówka, Warszawa 2000.

${ }^{3} \mathrm{~K}$. Ablewicz, Teoretyczne i metodologiczne podstawy pedagogiki antropologicznej. Studium sytuacji wychowawczej, Kraków 2003, s. 64, cyt. za: M. Ja w or sk a-Witk ow s ka, Ku kulturowej koncepcji pedagogiki. Fragmenty i ogarnięcie, Kraków 2009, s. 187. 
Antropologiczne spojrzenie - czy raczej wyobraźnia antropologiczna, by posłużyć się określeniem Andrzeja Mencwela ${ }^{4}$ - pozwala zatem zobaczyć, że istota szkoły polega nie tylko, a może nie przede wszystkim na transmisji kultury, wiedzy i kształceniu umiejętności czy na bezpośrednich oddziaływaniach wychowawczych, ale dotyczy całej sieci intersubiektywnych relacji, czasu i przestrzeni, teorii i praktyki pedagogicznej, które wpływają na doświadczenie człowieka, a zarazem go określają. Na użytek niniejszych rozważań proponuję przyjęcie uproszczonego rozumienia antropologii szkoły, u którego podstaw stoi myślenie o człowieku jako istocie uczącej się i nauczającej w sposób zorganizowany, systemowy, a zatem projektującej działania edukacyjne zarówno w wymiarze indywidualnym, jak i zbiorowym.

Grecki źródłosłów słowa szkoła (scholēe) kieruje ku pojmowaniu jej jako czasu, bo pierwotne znaczenie wiązało się z czasem wolnym, przeznaczonym na naukę, czyli na zaspokajanie potrzeb niezwiązanych bezpośrednio z funkcjami życiowymi. Myślenie o szkole jako o określonej przestrzeni albo o budynku (locus educandi) prowadzić może do rozpoznawania jej jako miejsca antropologicznego, czyli takiego, które ma walor tożsamościowotwórczy, czy - by użyć słów Ricoeura - jest „miejscem źródłowej orientacji”. Ukazanie szkoły jako miejsca doświadczanego przez jednostkę (,działanie” miejsca) lub/i określającego jej egzystencjalne doświadczenie (,oddziaływanie miejscem”) daje wgląd w kontekst antropologiczny oraz społeczny epoki. Przypisywanie szkole pewnych funkcji czy określeń, np.: wtajemniczania w wiedzę (świątynia), oddzielania od dotychczasowego środowiska (więzienie, koszary) odsłania proces społecznego kształtowania jej znaczeń i ukazuje ośrodki szkolne jako artefakty kulturowe. To z kolei kieruje uwagę na tak ważny, zwłaszcza w nowożytności, instytucjonalny wymiar szkoły, utrzymywanej między innymi po to, by oddziaływać na jednostkę i grupę, służyć formowaniu społecznych oraz indywidualnych postaw.

Już ten krótki, szkicowy zarys pozwala wyłonić kilka węzłowych zagadnień, które wyznaczają różne kierunki refleksji. Skupia się ona wokół takich pojęć, jak: miejsce antropologiczne (w ujęciu M. Augé), technologia władzy (M. Foucault), przemoc symboliczna (P. Bourdieu), podmiotowość i tożsamość jednostki oraz jej relacja do grupy (F. Znaniecki) ${ }^{5}$. Wszystkie te aspekty nie tyle sumują się, co łączą, dając - jak byśmy dziś powiedzieli - efekt synergii. To sprawia, że szkolna edukacja okazuje się skomplikowaną praktyką dnia codziennego, w której ujawnia się ewoluująca w czasie i nieustannie się odnawiająca koncepcja człowieka.

${ }^{4}$ A. Me n c we 1, Wyobraźnia antropologiczna. Próby i studia, Warszawa 2006.

${ }^{5}$ Por. M. Augé, Nie-miejsca. Wprowadzenie do antropologii hipernowoczesności, przeł. R. Chymkowski, przedm. Burszta, Warszawa 2010; M. F o u c a ul t, Nadzorować i karać. Narodziny więzienia, przeł. T. Komendant, Warszawa 1998; S. J. B a11, Foucault i edukacja. Dyscypliny $i$ wiedza, przeł. K. Kwaśniewicz, Kraków 1998; P. B o u r d i e u, Sur le pouvoir symbolique, „Annales" 1977, t. 32, nr 3, s. 405-411; P. B our r i e u, J.-C. P a s s e ro n, Reprodukcja. Elementy teorii systemu nauczania, przeł. E. Neyman, Warszawa 2006; F. Zn a nie c ki, Socjologia wychowania, wychowujqce społeczeństwo, t. I, Urabianie osoby wychowanka, t. II, Warszawa 2001. 
Literatura daje możliwość równoczesnego wglądu w rozmaite aspekty i wymiary tej praktyki, a jednocześnie uwidacznia pewne problemy i zjawiska, które umykają innym rodzajom refleksji - czyni je społecznie dostrzeganymi. Wolfgang Iser, odpowiadając na pytanie, czym jest antropologia literatury, zauważa: „Jako zjawisko towarzyszące ludzkiemu rozwojowi, literatura wydaje się być zwierciadłem, w którym przegląda się ludzkość ubrana we wszystkie wytwory i przejawy kultury" ". Obraz ten siłą rzeczy uwzględnia również to, co wiązało się z coraz mocniejszym uczestniczeniem instytucji szkolnej w życiu indywidualnym i społecznym.

W II połowie XIX w. i na początku XX stulecia temat szkoły pojawiał się w tekstach całej plejady twórców różnych pokoleń, np. T. T. Jeża, J. I. Kraszewskiego, J. Lama, E. Orzeszkowej, A. Dygasińskiego, B. Prusa, I. Maciejowskiego, G. Zapolskiej, S. Żeromskiego, W. Berenta, T. Micińskiego, J. Korczaka, J. Bandrowskiego, a nawet sporadycznie S. Brzozowskiego, K. Irzykowskiego czy Z. Nałkowskiej oraz w pracach pisarzy minorum gentium, których długiego szeregu nie będę tutaj wymieniać. O wszystkich autorach można jednak powiedzieć, iż nie pisali o szkole beznamiętnie. Utopijne, idealistyczne, wyrastające z marzeń projekty edukacji zderzają się z karykaturalnymi, sarkastycznymi, a niekiedy groteskowymi przedstawieniami szkolnej rzeczywistości, nie brakuje też ujęć sentymentalnych. Ogólne spojrzenie na zbiór wielu utworów pozwala stwierdzić, że dominują przedstawienia krytyczne. By zakreślić rozmaitość, niekiedy biegunowość ujęć i różnorodność zagadnień, skupię się na dwóch powieściach, jednej autorstwa Żeromskiego, drugiej - Korczaka. Nim jednak do tego przejdę, potrzebne jest drugie wyjaśnienie, dotyczące wybranego czasu, czyli udzielenie odpowiedzi na pytanie, dlaczego przełom XIX i XX wieku, a nawet nieco szerzej: druga połowa dziewiętnastego i początek kolejnego stulecia - jest okresem, jeśli chodzi o problematykę szkoły, szczególnie ważnym.

\section{WYJAŚNIENIE DRUGIE - DLACZEGO UBIEGŁY PRZEŁOM STULECI?}

Wśród wielu czynników określających funkcjonowanie edukacyjnych projektów i systemów na przełomie stuleci, tj. czasu, w którym narastało i kształtowało się doświadczenie nowoczesności, najbardziej istotny kontekst dla omawianych tutaj utworów stanowią trzy zjawiska ${ }^{7}$. Druga połowa XIX wieku to okres nasilenia refleksji pedagogicznej w Europie, z kolei przełom XIX i XX stulecia przynosi rozwój teorii i praktyki szkoły progresywistycznej w Stanach

${ }^{6}$ W. Is e r, Czym jest antropologia literatury, przeł. A. Kowalcze-Pawlik, „Teksty Drugie” 2006, nr 5, s. 34.

${ }^{7} \mathrm{Na}$ boku pozostawiam m. in. kwestię kształcenia kobiet, ich dostępu do szkolnictwa średniego i nasilające się apele o koedukację. Na marginesie tylko zaznaczę, że ciekawy zapis procesu wchodzenia dziewcząt do męskich szkół średnich przynosi książka Sándora Má ra i e g o Pierwsza miłość, ukazująca zmiany z perspektywy niechętnego im nauczyciela łaciny. 
Zjednoczonych, na obu kontynentach rozwijają się liberalne koncepcje edukacyjne $^{8}$. Przede wszystkim jednak rozszerza się szkolnictwo ludowe i pojawiają pytania o sposób jego organizacji. W literaturze wyraz tych tendencji znajdziemy np. w twórczości Żeromskiego - i to nie tylko w znanym opowiadaniu Siłaczka, ale i w dramacie Róża, a najmocniej w króciutkim tekście Na pokładzie. Podkreślić należy, że powszechne nauczanie - zgodnie z oświeceniową ideą - odbierane było jako znak postępu, dokonującego się w życiu społecznym, cywilizacyjnym, ale i zachodzącego na polu etyki. Żywo dyskutowano wówczas kwestię związku oświaty i etyki. Spór w tej materii toczyli m.in. B. Prus z A. Dygasińskim ${ }^{9}$; autor Lalki twierdził, że edukacja szkolna nie ma bezpośredniego wpływu na podniesienie moralności ${ }^{10}$, w ten sposób zakwestionował jeden z dogmatów, na których opierał się pozytywistyczny program. To wywołało stanowczy sprzeciw Dygasińskiego czy Świętochowskiego ${ }^{11}$. Rozbieżność stanowisk wynikała z odmiennych funkcji przypisywanych edukacji - położeniu akcentu przede wszystkim na transmisję wiedzy u pierwszego, a na wychowanie u jego adwersarzy.

Kolejny ważny wątek edukacyjnej batalii dotyczył funkcjonowania oraz modelu szkolnictwa średniego, jego roli i kształtu. Jak za Johnem Neubauerem przypomina Ewa Paczoska, procesy modernizujące, które zachodziły w społeczeństwach, takie jak: urbanizacja, industrializacja, rozwój middle class, przyczyniły się do rozpowszechnienia tego etapu nauki szkolnej, a w konsekwencji do zastąpienia wychowania domowego przez szkołę. Wydzielenie tego okresu rozbudziło powszechną świadomość, że dojrzewanie jest szczególnym momentem życia ${ }^{12}$. W tej sytuacji szkoły stanowiły nie tylko czasoprzestrzeń przejścia między życiem prywatnym a publicznym, ale ich zadaniem było także zagospodarowywanie czasu między dziecięctwem a dojrzałością ${ }^{13}$, dlatego przyznawano tym instytucjom doniosły wpływ na kształtowanie jednostkowej i zbiorowej podmiotowości. $\mathrm{Z}$ tego też powodu wiele emocji budził w XIX w. spór o modele wykształcenia.

Neoklasycystycznemu gimnazjum (jego projekt, wprowadzony w szkole pruskiej przez Humboldta, rozpowszechniał się od początków XIX w.) przeciwstawiano szkoły realne, $\mathrm{tj}$. nakierowane pragmatycznie na kształcenie konkretnych

${ }^{8}$ G. L. Gu te k, Filozoficzne i ideologiczne podstawy edukacji, przekł. A. Kacmajor, A. Sulak, posł. B. Śliwerski, Gdańsk 2003, s. 171-198.

${ }^{9}$ Polemika z Prusem o zwiqzek oświaty z moralnościq [w:] A. Dy g as iń sk i, Pisma pedagogiczne, oprac. i wstępem opatrzył W. Danek, Wrocław 1957, s. 104-125.

${ }^{10}$ B. Pru s, Oświata, „Nowiny” 1882, nr 302. W polemikach podtrzymywał to stanowisko, stwierdzając, że „Na drzewie cywilizacji konar »moralności« nie wyrasta z konaru »oświaty«, ale istnieje obok niego, rozwija się niezależnie". B. Pru s, Pierwsze strzały [w:] Polemika z Prusem..., dz. cyt., s. 108.

${ }^{11}$ Por. T. So bie raj, Prus versus Świętochowski. W sporze o naukowość, krytykę pozytywnq $i$,Lalke”, Poznań 2008, s. 10-15.

${ }^{12}$ E. Pac zos ka, Dojrzewanie, dojrzałość, niedojrzałość. Od Bolestawa Prusa do Olgi Tokarczuk, Warszawa 2004, s. 89.

${ }_{13}$ Por. A. C z a b a n o w s k a - W rób e 1, Dziecko. Symbol i zagadnienie antropologiczne w literaturze Młodej Polski, Kraków 2003, s. 17-18. 
umiejętności, ważnych w praktyce życia codziennego, społecznego. Odpowiedź na pytanie: ,gimnazja klasyczne - ogólnokształcące czy szkoły realne” dzieliła dyskutantów, ujawniała różnice poglądów nie tylko na cele i ideały wychowania, ale także na naturę ludzką, możliwości poznawcze, wartość wiedzy, a nawet na sposób istnienia wartości, przede wszystkim jednak wiązała się z modelem funkcjonowania w kulturze. Wśród przeciwników specjalizacji był m.in. znany filozof Henri Bergson ${ }^{14}$, natomiast pragmatyczne stanowisko prezentował Herbert Spencer.

Krytyka dominacji klasycznego wykształcenia, które nie przygotowywało młodych do podejmowania zawodowych zadań, była rozpowszechniona. Nie jest przecież przypadkiem, że jednym z głównych „szkolnych bohaterów” literatury, najczęściej negatywnie przestawianym, jest nauczyciel greki. Czechow ukazał go jako „człowieka w futerale" ${ }^{15}$, złośliwego belfra, który, zatopiony w przeszłości, odgradza się od innych zaporą przyzwyczajeń i boi aktywnego życia. Podobny portret rysuje Andrzej Niemojewski w obrazku Didomi, w pierwszym zdaniu rozwijając stereotypowe przeświadczenia: „Siedział po uszy w greczyźnie i gardził światem nowożytnym jak uczciwy filolog"16. Oderwanie od rzeczywistości, ucieczkę w starożytną przeszłość piętnował Brzozowski w Płomieniach. Z ust umierającego gimnazjalisty padają tam jedne z najcięższych oskarżeń przeciwko systemowi nauczania, przeciw edukacji, która, nastawiona na zgłębianie przeszłości, nie przygotowuje młodego człowieka do samodzielnego kierowania swoim życiem, a przede wszystkim do traktowania egzystencji jako twórczego zadania.

Żądanie zmiany programów, czyli odejścia od nauczania „martwych języków”, miało także bardzo realny wymiar i pragmatyczne konsekwencje, wiązało się z postulatem przygotowania uczniów do dorosłego życia i podejmowania przez nich działalności zawodowej. Dyskusji o szkołach klasycznych i realnych patronowały zatem odmienne modele absolwenta: homo eruditus lub homo faber. O iluzoryczności takiego przeciwstawienia i kryjącym się za nim uproszczeniu mówi wczesna powieść Wacława Berenta pt. Fachowiec, pokazująca młodego człowieka, absolwenta gimnazjum klasycznego, który nie jest przygotowany do samodzielnego, świadomego, twórczego bycia, lecz bezrefleksyjnie przyjmuje różne społeczne wmówienia ${ }^{17}$.

${ }^{14}$ H. B erg s o n, Wykłady o wychowaniu, przekł. P. Kostyło, Warszawa 2004, s. 7-17, wykład $O$ specjalizacji, wygłoszony podczas wręczania nagród w liceum w Angers, 3 kwietnia 1882 r.

${ }_{15}$ A. Czechow, Człowiek w futerale. Opowiadania, tłum. M. Dąbrowska, J. Wyszomirski, Warszawa 1967.

${ }^{16}$ A. Niemojewski, Didomi [w:] te go ż, Poezje prozq. (Obrazy), Kraków 1891. http:// www.pbi.edu.pl/book_reader.php?p=42131\&s=1.

Pozytywne wizerunki nauczycieli greki, którzy jednak nie są rozumiani i akceptowani przez uczniów, niesie Spowiedź motyla K or c z a k a czy Niebo w płomieniach P a r a n d o w sk ie go.

${ }_{17}$ Por. interpretację E. Pa cz oski ej w tekście Dojrzewanie - problem percepcji [w:] tejże, Dojrzewanie, dojrzałość..., dz. cyt., s. 57. 
Batalia o programy nauczania, przedmioty i zakres oraz sposób ich nauczania okazały się de facto batalią o model edukacji, ten nastawiony na kultywowanie ciągłości kulturowej, zakorzenienie w przeszłości, czy ten wychylony ku przyszłości, u którego podstaw leży myślenie o postępie, o nieodwracalnym charakterze zmian, które dokonywały się w złożonym procesie „unowocześniania” świata ${ }^{18}$.

Nie da się też nie zauważyć, i to trzeci ze wspomnianych na początku czynników, że wraz z rozwojem systemów kształcenia i powszechnością edukacji nasilił się nurt krytyczny wobec szkoły. Znana szwedzka pisarka, nauczycielka i pedagog Ellen Key, w głośnej książce Stulecie dziecka już w 1900 r. ${ }^{19}$ postulowała przekroczenie/odrzucenie szkoły, przekonywała, że: „Wielkim a jedynym zadaniem szkoły jest uczynić się zbyteczną; w miejsce systemu i schematu wprowadzić życie i szczęście, [co znaczy także, innymi słowy, czynić samodzielną]"20. Do takich radykalnych wniosków skłaniał ją automatyzm kształcenia, brak uwzględnienia potrzeb jednostki. Dodajmy od razu, że przeciwników szkolnej instytucji było więcej, występowali oni z różnych stanowisk. Jednym z oponentów, w dodatku należącym do najbardziej zagorzałych, był Stanisław Witkiewicz. W Dziwnym człowieku pisał:

W naszych czasach, czasach systemów szkolnych, gdzie „szkolarstwo” uważa się za wiedzę, gdzie szkoła jest w absolutnej niezgodzie z psychologią człowieka, gdzie metody uczenia i cele nauki nie mają nic wspólnego z człowiekiem żywym i życiem rzeczywistym [...] w naszych czasach zabija się na marne, na nic drze się na strzępy i zamienia się w śmiecie najdzielniejsze, najlepsze siły młodej duszy [...]. System szkolny bierze dziecko w szóstym roku życia i puszcza dwudziestoletniego człowieka, po czternastu latach ciężkich robót, „ze świadectwem dojrzałości w kieszeni”, duszą naderwaną, przepojoną wiarą w patenty, miejsca, stanowiska, kariery obstawione przywilejami, wynikającymi z ukończenia szkoły - ze zdania matury ${ }^{21}$.

Namiętna filipika wynikała z przekonania Witkiewicza, że współczesna mu szkoła niszczy samodzielność młodych, odbiera im twórcze siły i formatuje osobowość.

Z przytoczonych powyżej stanowisk widać, że myślenie o szkole naznaczone było ambiwalencją. Powszechnie podnoszona opinia o konieczności rozwoju zorganizowanego nauczania, unowocześniania tej praktyki życia codziennego, zwłaszcza w zakresie szkolnictwa ludowego i średniego, spotykała się z głosami krytycznymi, domagającymi się wyzwolenia dzieci z instytucjonalnego przymu-

${ }^{18} \mathrm{O}$ nieodwracalności zmian i idei postępu jako cesze nowoczesności por. Z. B a u m a n, Prawodawcy i tłumacze, przeł. A. Tanalska [w:] Postmodernizm. Antologia przekładów, red. R. Nycz, Kraków 1996, s. 269-298.

${ }_{19}$ Na język polski publikacja ta została przetłumaczona już w $1904 \mathrm{r}$.

${ }^{20}$ E. K ey, Stulecie dziecka, przekł. I. Moszczeńska, Warszawa 2005, s. 150.

${ }^{21}$ S. Witki ewi cz, Dziwny człowiek, Lwów 1903, s. 24-25. Przypomnę, że Witkiewicz nie tylko krytykował system edukacji, ale też prowadził eksperyment pedagogiczny - swego syna nie posłał do szkół, lecz sam kierował jego edukacją i wychowaniem. 
su. Ta dwukierunkowość uwag sprzyjała ujawnieniu i opisaniu procesu nieustannego przekształcania „odrzuconego” w „konstytutywne” - i na odwrót. Wspólne, ponad rozbieżnościami w ocenie szkoły, było jednak przekonanie, że jest to instytucja, która ustala, weryfikuje/określa los pojedynczej jednostki, współtworzy zjawiska tak różne, jak normatywność tradycji, zasady budowania więzi wspólnotowych, stabilność habitusu, a jednocześnie podporządkowuje indywidualny rozwój społecznym czy politycznym założeniom. Toteż krytyczna diagnoza instytucji wynikała z dostrzeganych trudności w pogodzeniu sprzecznych, wydaje się, celów, jakie przyświecały nowoczesnym edukacyjnym projektom: kształtowania niezależnej, wolnej jednostki i żyjącej w harmonii zbiorowości. Zwracał już na to uwagę Fryderyk Nietzsche, gdy w dziele Ludzkie, arcyludzkie pytał:

jak dane indywiduum daje się dopasować do tych [...] różnych wymagań kultury, żeby go one jednak nie niepokoiły i jednolitości jego nie rozszczepiały - krótko mówiąc, w jaki sposób indywiduum może być wciągnięte do kontrapunktu prywatnej i publicznej kultury, w jaki sposób może prowadzić jednocześnie melodię i będąc melodią, jednocześnie służyć jej za akompaniament?22

\section{STARA I NOWA SZKOŁA}

Czas przejść do zasygnalizowanych w pierwszej części tego szkicu tekstów Żeromskiego i Korczaka. Pierwszy z nich to klasyka powieści szkolnej ${ }^{23}-S y$ zyfowe prace. Utwór tyleż oczywisty w tym zestawieniu, co kłopotliwy. Oczywisty - bo niemożliwy do pominięcia, istniejący w pamięci zbiorowej i kulturowej, kształtujący stosunek Polaków do szkolnej zaborczej instytucji. Kłopotliwy, ponieważ poprzez fakt wieloletniego istnienia na listach szkolnych lektur unieruchomiony został w swoich skanonizowananych odczytaniach tak mocno, że stanowi niemal skamielinę interpretacyjną ${ }^{24}$. Natomiast drugi z przywoływanych tekstów to mało znana, fantastyczna powieść Janusza Korczaka zatytułowana Szkoła życia. Autor nie ogłosił jej w wydaniu książkowym, była jedynie drukowana wpierw w „Przeglądzie Społecznym”, potem w „Społeczeństwie” - pismach stanowiących kontynuację ,Głosu” Jana Dawida ${ }^{25}$.

${ }^{22}$ F. Nietz s che, Ludzkie, arcyludzkie, przeł. K. Drzewiecki, oprac. R. Mitoraj, posłowie P. Pieniążek, Kraków 2004, s. 153.

${ }^{23}$ Wzorzec powieści szkolnej w literaturze polskiej uformowały utwory: Nad poziomy (1887) W. Sabowskiego, sygnowane pseudonimem: Wołody Skiba; Syzyfowe prace (1897) S. Żerom skie go; Wspomnienia niebieskiego mundurka (1906) W. Go mu licki e g o. Por. J. Pa puz iń sk a, Mój bajarz. Studia i szkice o literaturze młodzieżowej, Warszawa 2010, s. 47-48.

${ }^{24}$ Lista pozycji bibliograficznych dotyczących powieści jest obszerna, przyczynił się do tego także fakt, że utwór należał do kanonu lektur szkolnych. Tutaj warto jedynie przypomnieć, że powieść doczekała się monografii, jest nią studium W. Sło d k o w sk i e g o, „Syzyfowe prace” Stefana Żeromskiego, Wrocław 1966.

${ }^{25}$ Pierwsze książkowe wydanie miało miejsce w 1998 r.: J. K or c zak, Szkoła życia [w:] te g o ż, Szkoła życia, Obrazki szpitalne, Artykuły pedagogiczne i metodyczne (1900-1912), Dzieła, t. 4, Warszawa 1998, s. 5-141. Wszystkie cytaty pochodzą z tego wydania. 
Daty wydania omawianych tekstów dzieli jedynie 10 lat. Można zatem powiedzieć, że choć proponują różną perspektywę opisu, odnoszą się do tego samego historycznego doświadczenia. Opublikowane w roku 1897 r. Syzyfowe prace ukazują szkołę dziewiętnastowieczną. Żeromski - co powszechnie wiadomo stworzył swoją powieść, odnosząc się do autobiograficznych doświadczeń, lecz też po zapoznaniu się z pracą Romana Dmowskiego Gimnazja rosyjskie w Polsce. Szkic wychowawczy ${ }^{26}$. Utwór przynosi obraz szkoły pod zaborami, mającej swój analogon w rzeczywistości, i wpisuje się, na co zwracał uwagę już Wacław Borowy ${ }^{27}$, w zbiór powieści o dojrzewaniu. Natomiast wychodząca w latach 1907-1908 Szkoła życia to utopia literacka. W metatekstowym komentarzu czytamy, że ,jest to powieść fantastyczna, osnuta na tle istniejącej jakoby wzorowo zreformowanej szkoły, która służy celom całej ludzkości, a nie - nielicznej klasy posiadającej" 28 . W jej projektowaniu Korczak twórczo wykorzystał idee reformatorów wychowania, aluzyjnie odniósł się do powstających w tym czasie „szkół pracy” w Niemczech, reformy Georga Kerschensteinera, chicagowskiego eksperymentu Johna Deweya, a także idei swobodnego wychowania, rozwijanej przez Lwa Tołstoja. Przede wszystkim jednak opisany eksperyment edukacyjny ma swe źródła w dokonanej przez pisarza-pedagoga rewizji założeń i praktyki wychowawczej, czyli w innym spojrzeniu na dzieciństwo i uznaniu dziecka za samostanowiący o sobie podmiot, który rozwija się poprzez własną aktywność. Skrótowo poglądy pisarza-pedagoga wyraża używane przez niego stwierdzenie: „Nie ma dzieci, są ludzie”; to antropologiczne założenie sprawiło, że współcześnie dostrzega się w autorze Dziecka salonu prekursora nurtu antypedagogiki.

Wspólny punkt odniesienia dla utworów Żeromskiego oraz Korczaka - i to zarówno, gdy idzie o praktykę pedagogiczną, jak i kryjącą się za nią koncepcję człowieka - stanowi działalność Pestalozziego, szwajcarskiego pedagoga, który był zwolennikiem powszechnego nauczania, swobodnego rozwoju wrodzonych uzdolnień ucznia, pobudzania jego samodzielnej aktywności poznawczej, a także rzecznikiem nauczania poglądowego ${ }^{29}$. Żeromski pokazuje, że szkolna codzienność zaprzecza ideałom Pestalozziego - natomiast Korczak, który w Szwajcarii zapoznawał się ze sposobem ich realizowania, twórczo je rozwija, choć w jego

${ }^{26}$ Żeromski na prośbę Dmowskiego dokonał korekty tej pracy, wyszła ona w 1893 roku w Paryżu staraniem Zygmunta Miłkowskiego.

${ }^{27}$ W. B orow y, Powieść o dorastaniu (Żeromskiego „Syzyfowe prace”) [w:] te g o ż, O Żeromskim. Rozprawy i szkice, Warszawa 1964.

28 J. Korc zak, Szkoła życia, dz. cyt., s. 6.

${ }^{29}$ Pestalozzi swoje poglądy pedagogiczne sformułował $w$ wielu pismach, między innymi w trzykrotnie opracowywanej powieści Leonard i Gertruda, w której pokazywał konieczność upowszechniania wykształcenia elementarnego jako podstawy społecznego odrodzenia, czy w napisanym pod koniec życia utworze pt. Łabędzi śpiew, gdzie przedstawiał czytelnikom swoje poglądy, doświadczenia i opisywał przyczyny niepowodzeń. Por. J. H. P e s ta lo z zi, Łabędzi śpiew, przekł., wstęp i oprac. R. Wroczyńska i R. Wroczyński, Wrocław 1973. Żeromski opisuje działalność elementarnych szkół szwajcarskich w króciutkim opowiadaniu Na pokładzie. 
utworze nie pojawia się bezpośrednie odwołanie do autora Leonarda i Gertrudy $y^{30}$. Nazwisko Pestalozziego na zasadzie kontrapunktu przywołane zostało natomiast w Syzyfowych pracach. Co szczególnie znaczące, przypomina je rosyjski inspektor, który w chwili nostalgii, po wizycie w szkole ludowej w Psarach, uświadomił sobie, że to, co robi, zaprzecza ideom formującym jego nauczycielskie powołanie:

Po ukończeniu studiów na wydziale filologicznym w Moskwie Jaczmieniew, zapalony ludowiec, zdecydował się ,iść między naród”, osiąść w szkole wiejskiej. Pragnąc wszakże zdobyć i przyswoić sobie metodę pracy, która by dawała plony jak najobfitsze, odbył wycieczki do Szwecji, Anglii, Niemiec i Szwajcarii, i we wszystkich tych krajach pilnie studiował szkolnictwo ludowe [...]. Ach, cóż by dał, ażeby wrócić do tamtej młodości, toczyć długie rozprawy z uczciwymi belframi wiejskich szkółek szwajcarskich, długo w noc z nimi radzić o sposobach zniesienia ciemnoty w „strasznej Rosji” i mieć w piersi prawe, szlachetne serce! [...]. Przeszło, minęło niepowrotnie, rozwiało się niby mgła nad jeziorem. Wczoraj zda się człowiek z kijem w ręku łaził po skałach, ażeby się nauczyć, jak najlepiej, najszybciej, najhumanitarniej rozniecać światło wpośród ciemnych mas chłopskich, a dziś... Nie należy szerzyć oświaty w kosmopolitycznym znaczeniu tego wyrazu, lecz należy szerzyć „oświatę rosyjską”. Na to zdał się cały Pestalozzi... ${ }^{31}$

Wpisując w rozważania Jaczmieniewa pytanie zarówno o cel, jak i sposoby kształcenia, Żeromski poruszył problem funkcjonowania systemu szkolnego, który został przejęty przez instytucję obcego państwa i miał na celu wychowanie jednostek podległych zaborcy, ich zakorzenienie w innej kulturze, co w rezultacie - wszak dziecko to przyszły dorosły ${ }^{32}$ - winno doprowadzić do pożądanej przez władze zmiany nastawienia społecznego. Syzyfowe prace, co pragnę podkreślić, dzięki ukazaniu zabiegów rusyfikacyjnych można odbierać jako tekst pokazujący te mechanizmy zinstytucjonalizowanej edukacji i szkolnej opresji, które nie ujawniałyby się tak wyraźnie w innych okolicznościach historycznych, a nawet w ogóle mogłyby nie dojść do głosu. Powieść działa jak swoiste szkło powiększające, bo wydobywa zasady projektowania i funkcjonowania inżynierii społecznej. Uwidaczniają się one także w rozważaniach rosyjskiego urzędnika:

Pragnąc za pomocą zruszczenia tych chłopów polskich istotnie przyczynić się do szybkiego rozwoju Północy na drodze cywilizacji, należałoby to zrobić tak skutecznie, ażeby chłop tutejszy

${ }^{30} \mathrm{Na}$ marginesie trzeba dodać, że nazwisko szwajcarskiego reformatora w dziewiętnastowiecznej literaturze funkcjonowało jako hasło uaktywniające $\mathrm{w}$ odbiorze odniesienie do nowych tendencji pedagogicznych. W tej roli pojawia się m.in. u Dygasińskiego, ale w XX w. staje się znakiem anachronicznych poglądów edukacyjnych np. w opowiadaniu Jarosława I w a s z k i e w i c z a pt. Nauczyciel.

${ }^{31}$ S. Że rom s ki, Syzyfowe prace, oprac. A. Hutnikiewicz, wyd. II, Wrocław 1984, s. 42-44. Wszystkie cytaty pochodzą z tego wydania.

${ }_{32}$ T. Buliński, Kulturowy wymiar wychowania: praktyki i ideologie [w:] Wychowanie. Pojęcia, procesy, konteksty, red. M. Dudzikowa, M. Czerepniak-Walczak, t. I, Gdańsk 2007, s. 105108. 
ukochał Rosję, jej prawosławną wiarę, mowę, obyczaj, ażeby za nią gotów był ginąć w wojnie i pracować dla niej w pokoju. Trzeba by wydrzeć z korzeniami tutejszy, iście zwierzęcy, konserwatyzm tych chłopów. Trzeba by zburzyć tę odwieczną, swoistą kulturę niby stare domostwo, spalić na stosie wierzenia, przesądy, obyczaje i zbudować nowe, nasze, tak szybko jak buduje się miasta w Ameryce Północnej. Na tym gruncie dopiero można by zacząć wypełnianie marzeń pedagogów szwajcarskich [Syzyfowe prace, s. 44].

Bohater ma pełną świadomość kulturowych kontekstów edukacji, rozumie, że mowa, obyczaj, wiara określają warunki kształcenia i wpływają na jego skuteczność, czyli mówiąc socjologicznym językiem, niosą matryce poznawcze, schematy postrzegania, leżą u podstaw habitusu. Z tego powodu szkoła wroga kulturowym, historycznym doświadczeniom ludności nieuchronnie obnaża, a nawet eksponuje swoją symboliczną przemoc. Przymus posługiwania się obcą mową zamiast rodzimym językiem, uniemożliwiał odnoszenie edukacyjnych doświadczeń do kreowanego przez niego i w nim obrazu świata, stanowił zatem potężną barierę edukacyjną. Niemożność jej przekroczenia opisał Sienkiewicz w noweli Z pamiętnika poznańskiego nauczyciela, natomiast w Syzyfowych pracach Żeromski wskazał zjawisko dwójmyślenia, polegające na myśleniu o sferze prywatnej po polsku, a o rzeczach naukowych oraz sprawach abstrakcyjnych po rosyjsku, bo w tym języku poznawano terminy je opisujące. W ten sposób powstawała podwójna świadomość, a jednocześnie skutecznie, niewidocznie działała symboliczna przemoc ${ }^{33}$.

Z drugiej jednak strony, zderzanie różnych symbolicznych kodów: narodowych (polskość - rosyjskość) czy religijnego i naukowego, czego przykłady daje pisarz w scenach na lekcjach historii, religii, literatury czy w epizodzie w teatrze, sprzyjało uwidacznianiu sytuacji opresji. Fakt, że to, co oficjalne, pozostawało w konflikcie z tym, co prywatne, powodował zakłócenie rytmu szkolnej codzienności i prowadził do ujawnienia pokładów nieuświadamianych wcześniej treści, które kształtowały zachowania i poglądy. Pojawiało się wówczas miejsce na sprzeciw.

I jeszcze jedno, wpływ symbolicznej przemocy jest szczególnie silny, gdy szkoła pozostaje miejscem izolacji młodych, a jednocześnie stanowi konieczny warunek do społecznego awansu. Gimnazjum w Klerykowie pokazane zostało

${ }^{33}$ „Na dysputach wieczornych wszystko, cokolwiek tyczyło się rzeczy »abstrakcyjnych«, wypowiadano między sobą po rosyjsku. Nikt »przekonań « swych po polsku nie umiałby ze ścisłością wyłożyć. Była to najbardziej zjadliwa forma obrusienja, bo dobrowolnie, we wnętrzu własnych czaszek stopniowo zaprowadzana przez młodzież" [s. 206].

W tym kontekście warto zaznaczyć, że współczesny socjolog edukacji B. Bernstein podkreślał rolę języka jako symbolicznego przewodnika po kulturze, nazywał język filtrem, przez który jednostka odbiera rzeczywistość, jednocześnie ją przekształcając. Co więcej, wskazywał, że ,przez mowę jednostka kształtuje przyjęty w danej grupie styl poznawczy", co ma ogromne znaczenie w procesie socjalizacji. Por. J. B i eleck a-Prus, Transmisja kultury w rodzinie i szkole. Teoria Basila Bernsteina, Warszawa 2010, cyt. s. 32. 
jako enklawa rządząca się swoimi prawami (by umożliwić do niego wstęp synowi, matka Marcina Borowicza zmuszona była do szukania protekcji). Jednocześnie stosowane tam metody indoktrynacji uczniów, przejmowania kontroli nad całym ich życiem, które opisał Żeromski także w innych utworach: w epizodzie z Urody życia czy opowiadaniu Nagi instynkt, sprawiały, że młodzi czuli się uwięzieni w systemie zależności, żyli w świecie panoptikonu (w pierwotnym sensie tego słowa), poddani ciągłemu nadzorowi. Jawna opresyjność systemu powodowała, że podejmowali grę z normami szkolnego i pozaszkolnego życia, które ograniczały ich wolność. Jednym z przykładów takiego działania było koło samokształceniowe, założone przez uczniów maturalnej klasy, na którym czytano teksty niedozwolone w szkole. Paradoksalnie zatem - instytucjonalny przymus, demaskując symboliczną przemoc, sprzyjał uruchamianiu mechanizmów obronnych.

Skomplikowanie, a jednocześnie dwubiegunowość oddziaływania zaborczej szkoły, jej przystosowawczy, a zarazem emancypujący wpływ pokazują zwłaszcza losy Radka. Znamienne, że zagrożony wyrzuceniem z gimnazjum po bójce z niechętnymi mu kolegami, nie znalazł w sobie sił, by opuścić szkolny dziedziniec. Fakt zatrzymania się przed przekroczeniem szkolnej bramy ujawniał jego lęk przed utratą określonego scenariusza społecznych zachowań oraz przed pozbyciem się zewnętrznych oznak, które czyniły z niego członka społeczności gimnazjalnej. Wyjście poza paradygmat uczniowskiej roli unieważniłoby wszystkie jego dotychczasowe osiągnięcia i zniszczyło marzenia na przyszłość. Brak alternatywy czynił go niemal niewolnikiem instytucji.

W dziejach Radka, choć przecież nie tylko jego, Żeromski zilustrował szerszy proces - dynamiczną zmianę stosunków społecznych, wynikającą z upowszechniania edukacji oraz rozrastania się warstwy inteligencji. Sentencjonalne i złośliwe uwagi rajców spotykających się na stancji pani Przepiórkowskiej, mówiących, że ,wszystko pcha się do fraka”, zwracają uwagę na fakt, że ówczesny ustrój szkolny prowadzi do rozrostu warstwy urzędniczej. Z perspektywy czasu widać bardziej złożone zjawiska, wynikające z upowszechniania wykształcenia średniego i wyższego. Po pierwsze, co opisał Jerzy Jedlicki ${ }^{34}$, nadprodukcję inteligencji, która nie mogła potem znaleźć pracy, po drugie, problem izolacji społecznej tych, którzy w swoich rodzinach byli pierwszym wykształconym pokoleniem ${ }^{35}$. W takim ujęciu symbolicznego znaczenia nabiera scena pożegnania Radka:

Rodzice obydwoje płakali, odprowadzając go daleko, daleko za pola folwarczne. Nie wiedzieli, jakim słowem przemówić na pożegnanie, zapewne ostatnie, co mu radzić, przed czym ostrzegać. Patrzyli tylko w milczeniu, pragnąc zachować w źrenicach obraz jego postaci. I Jędrek milczał

${ }^{34}$ J. Je dlicki, Jakiej cywilizacji Polacy potrzebujq. Studia z dziejów idei i wyobraźni XIX wieku, Warszawa 2002, s. 261-303.

${ }^{35}$ Na marginesie trzeba dopowiedzieć, że to także casus Judyma. 
[...] idąc po twardej szosie i nie oglądając się poza siebie, płakał i on cichymi chłopskimi łzami [s. 168].

Wraz z podjęciem decyzji o nauce w klerykowskim gimnazjum bohater rozpoczynał bowiem wędrówkę w nieznane obszary kultury, społecznych i egzystencjalnych doświadczeń, wędrówkę, w której nie mógł liczyć na przewodników wywodzących się z jego najbliższego otoczenia. Rozrastająca się sfera milczenia i narastającej obcości określała jego rodzinną relację, wyjście z domu skazywało Radka na rozpoznawanie własnej nieprzystawalności oraz inności, rodziło potrzebę szukania swego miejsca w przestrzeni społecznej. Szkoła nie ułatwiała mu tego procesu, ale niosła nadzieję na zmianę związaną z wykształceniem, dzięki któremu można było nadać znaczenie swej egzystencji. Instytucja określała zatem i częściowo determinowała dzieciństwo oraz młodość bohaterów, decydowała o ich dalszych losach.

Żeromski pokazał także drugi, obok zinstytucjonalizowanych działań, zasadniczy czynnik wpływający na jakość i kierunek edukacyjnego procesu, czyli wagę indywidualnego działania, przeżyć i doświadczeń, które rodziły się w przestrzeni intersubiektywnych relacji, oddziaływania grupy, jak i własnej aktywności ucznia. W powieści najpełniej ujawniły się one podczas recytacji na lekcji polskiego czy w wystąpieniu jednego z uczniów przeciw nauczycielowi historii. Dzięki nim Marcin Borowicz zaczął rozpoznawać własną drogę, zyskiwał wewnętrzną niezależność. Właśnie podmiotowość uczniów, ich indywidualne cechy, temperament czy poglądy naruszały jednorodność i spójność zaprojektowanego odgórnie systemu, sprawiały, że efekt szkolnych oddziaływań nie dał się do końca przewidzieć. Spojrzenie na szkołę od strony ucznia, poprzez pryzmat jego losów i życia wewnętrznego, podkreślało podmiotową perspektywę, umożliwiało wskazanie obszarów, na których mogła się przejawiać wolność jednostki. Wiara w możliwość zachowania tej wolności lub jej odzyskania stanowi u Żeromskiego podstawę myślenia o człowieku, o inteligencie zdolnym do twórczego przekształcania świata ${ }^{36}$. Gdy Marcin Borowicz kończy gimnazjum, wie na czym polega wewnętrzna niezależność. Jednocześnie po latach edukacyjnej kwarantanny jeszcze ostrzej widzi zło w świecie i cierpienie innych, zwłaszcza dzieci; wówczas rośnie w nim poczucie beznadziei, pojawia się też pytanie, co dalej:

Po cóż to wszystko ludzie robią, po co czynią dobrowolnie na złość słabszym spośród siebie, dzieciom? Toż to jest pomoc udzielona młodości przez wiek i rozum dojrzały? [s. 254]

Opuszczenie szkolnej enklawy, gdzie funkcjonowały już rozpoznane i oswojone mechanizmy, zaowocowało u niego doświadczeniem bezradności. To roz-

${ }^{36}$ T. So bieraj, Heroizm i antynomie nowoczesności. Wokót światopoglqdu Stefana Żeromskiego [w:] Światy Stefana Żeromskiego. Studia pod redakcją M. J. Olszewskiej i G. P. Bąka, Warszawa 2005, s. 401-421. 
poznanie bohatera kieruje nas ku najistotniejszej, patrząc z edukacyjnego punktu widzenia, kwestii, czyli pytania o rolę szkoły w przygotowaniu do samodzielnego życia, o jej tożamościowotwórczy charakter.

Obu pisarzy - Żeromskiego i Korczaka - łączy namysł nad wykorzystaniem zdobytej przez uczniów podczas edukacji wiedzy w życiu pozaszkolnym, a więc nad funkcjonalnością programów czy nad tzw. ukrytym programem nauczania, który poznać można, analizując nie to, co jest przepisane i ustanowione, ale to, co zostało pominięte - zastanawiając się także nad kryteriami doboru treści kształcenia, sposobem organizacji pracy. W Syzyfowych pracach nie ma, tak jak np. u Dygasińskiego (W Kielcach), Brzozowskiego (Płomienie) czy Korczaka - o czym za chwilę - bardzo ostrej krytyki. Pojawia się jednak - czyniona jakby z punktu widzenia uczniów - uwaga o niemożności zsubiektywizowania, uwewnętrznienia przez nich większości wprowadzanych treści:

Ani na jedną, ani na drugą grupę młodzieży przedmioty kursu klas ostatnich nie wywierały wpływu. Przeważna większość uczniów kształciła się tylko w matematyce, i ta nauka była czynnikiem istotnie rozwijającym umysły. Od klasy szóstej interesowano się również fizyką, aczkolwiek wykład jej prowadzony był niedołężnie. Resztę umiejętności, a więc języki starożytne, rosyjski, historię itd., uważano powszechnie za zło konieczne i cierpliwie tolerowano zjawisko, które można wyrazić za pomocą sentencji: non vitae sed scholae discimus [s. 197].

Powtórzmy: non vitae sed scholae discimus, właśnie owo gorzkie poczucie nieprzydatności zdobywanej wiedzy sprawia, iż szkolny mikrokosmos odbierany jest jako miejsce odizolowane od prawdziwego życia. Ten aspekt szczególnie mocno wyakcentowany został w Szkole życia.

Punktem wyjścia tej powieści jest bezwzględna krytyka systemu oświatowego, który nie tylko okazuje się niewydolny edukacyjnie, ale często niszczy siły, talent jednostki, nie stwarzając jej możliwości rozpoznania własnych zdolności, a przede wszystkim sensu indywidualnej egzystencji. „Stara szkoła” nazywana została policyjnym cyrkułem (s. 15), fabryką (s. 18), domem wariatów (s. 19), kazamatami (s. 22). W emocjonalnie nacechowanej narracji reformatora pojawiają się takie inwektywy, jak: ladacznica bezwstydna, sprzedajny kłamca, płatny ciemiężca dzieci (s. 21). Metaforyczne określenia lepiej niż beznamiętny dyskurs pozwalają wskazać przyczyny krytyki. Narratorska filipika jest ostra, a lista zarzutów długa, edukacyjna placówka zatem: zabiera wolność dzieciom, tłumi ich indywidualność, a poprzez poddawanie ujednoliconym wymogom i działaniom ,,produkuje miernoty"37,

37 „W każdej klasie czterdziestu uczniów i wszyscy uczą się tego samego. A przecież każdy z tych chłopców musi być trochę inny od reszty. - Więc dzieje się to samo, co w fabryce, gdzie przy tym samym zajęciu siedzi stu ludzi, z których każdy co innego myśli, co inaczej czuje, i do czego innego dąży" [s. 18].

„Stara szkoło niewolników i nieuczciwych urzędników, histeryków i błędnych owiec. Nawet zuchwałych rzezimieszków nie ty wychowywałaś, pragnąc tego - nic, tylko same miernoty. Długi 
przede wszystkim jednak, tworząc sztuczne środowisko ${ }^{38}$, nie przygotowuje uczniów do dorosłego życia:

Na całą szkołę patrzyłem jak na dom wariatów [...]. Było to także życie, ale jakieś sztuczne, jakby na żarty zrobione, a takie samo nieczyste, pełne obaw, niechęci, nieżyczliwości i kłamstwa - życie małych niewolników, dozorowanych przez nieuczciwych i znudzonych urzędników, dziwaków i półwariatów [s. 19].

Właśnie zamknięcie, nieprzystawanie do świata, system nadzoru, czyli te cechy, które Foucault przypisał heterotopii kryzysu ${ }^{39}$, są jednocześnie podstawowymi zarzutami Korczaka przeciwko szkole, która zniewala samodzielny podmiot. Przywołajmy jeszcze jeden cytat:

dziecko ośmioletnie zaczyna chodzić do szkoły, mijają lata za latami - już młodzieniec pod wąsem, a wreszcie dorosły mężczyzna, już mógłby mieć żonę i troje własnych dzieci - i precz się uczy jeszcze, i uczenie tyle mu czasu zabiera, że na nic innego już nie pozostaje mi ani chwili [s. 17].

Dla narratora, który prezentuje poglądy pisarza wyrażone w licznych artykułach oraz utworach literackich ${ }^{40}$, „martwa szkoła”, ,,szkoła śmierci” (to określenia z omawianej powieści) nastawiona była na utrzymywanie starego porządku, czylijak powiedzieliby Bourdieu i Passeron - na reprodukcję. Jej przeciwieństwem była „szkoła życia”, opisywana jako nowoczesny, racjonalny projekt, u podstaw którego leżało założenie, że proces edukacyjny polega na pomocy w rozpoznawaniu sensu indywidualnej egzystencji i ma na celu umożliwienie dzieciom odkrycia i rozwijania ich jednostkowych predyspozycji. Takie wychowanie winno zapobiec poczuciu przypadkowości losu i ukazać podstawową wartość, jaką jest życie w wolności:

życie dzisiejsze człowieka jest właśnie tylko garścią bezprzykładnie nie powiązanych wzajemnie wypadków - bez nici przewodniej, bez istotnego wewnętrznego sensu. - I temu zapobiec pragnie nasza szkoła [s. 10];

szereg wielkich samouków. Długi szereg wielkich wypędków - policzkował cię, szkoło kompromisów i pośredniej miernoty..." [s. 21].

${ }^{38}$ Szkołę jako sztuczne środowisko, będące przeciwieństwem zwykłego, codziennego, opisywał F. Znaniecki, wskazując przy tym, że: „Była ona [szkoła - M. R.] wyrazem dążenia starszego pokolenia do wydzielenia i odosobnienia tych jednostek spomiędzy młodzieży, które przygotowują się do czynnego udziału w życiu społecznym, aby uchronić je na czas przygotowania od wpływów zewnętrznych, uważanych za szkodliwe, natomiast tym łatwiej zogniskować na nich wpływy dobroczynne przez wytworzenie specjalnych, wyjątkowych warunków”. Dz. cyt., s. 102.

${ }^{39}$ M. Fo u c a u lt, Inne przestrzenie, przeł. A. Rejniak-Majewska, ,Teksty Drugie” 2005, nr 6, s. $120-121$.

${ }^{40}$ Krytykę szkoły zawarł Korczak m.in. w takich utworach, jak: powieściowym dzienniku zatytułowanym Spowiedź motyla, w opowiadaniu Feralny tydzień, z kolei w powieści Dzieci ulicy umieścił opis kolonii zarudzkiej, czyli eksperymentalnej placówki edukacyjnej. Jeśli idzie o artykuły, to przypomnę tylko jeden z wczesnych tekstów pt. Dzieci $i$ wychowanie, który został opublikowany w „Wędrowcu” $1900 \mathrm{r}$. 
czy:

zbudujemy szkołę, gdzie wychowańcy nie będą się uczyli martwych liter z martwej bibuły, gdzie natomiast uczyć się będą z tego, jak żyją ludzie, czemu tak żyją, jak inaczej żyć można, co umieć i co czynić należy, by żyć pełnią wolnego ducha [s. 13].

W powieści pomysłodawcą i wykonawcą projektu jest pełniący rolę narratora samouk-reformator, który przypadkowo stał się spadkobiercą ogromnego majątku i postanowił go wykorzystać na realizację swojej idei. Pierwszą część utworu stanowią wspomnienia, dotyczące tych życiowych doświadczeń bohatera, które legły u podstaw jego pedagogicznego eksperymentu. Drugą z kolei tworzą kartki pamiętnika, mowy, luźne uwagi, składające się na opis placówki. Ten swoisty kolaż tekstów pozwala na pokazanie detali, ale też ogólnych zasad funkcjonowania edukacyjnego projektu.

Utwór Korczaka, jak wiele utopii, w tym znana w owym czasie powieść Edwarda Bellamy’ego W wieku XXI, daje panoramiczny, a zarazem szczegółowy obraz zaproponowanych rozwiązań. Rzecz nie rozgrywa się jednak ani w odległej przyszłości czy w mitycznej, nieokreślonej przeszłości, wręcz odwrotnie, współczesne pisarzowi realia są wyraźnie przedstawione, a ówczesna szkoła potraktowana jest jako negatywny punkt odniesienia. W przeciwieństwie do niej nowa szkoła nie stanowi zamkniętej placówki, wręcz odwrotnie, jest jakby światem w miniaturze, przypomina swoistą kolonię, którą tworzą ułożone w podkowę budynki o różnym przeznaczeniu. Znajdują się tam m.in.: czytelnia i ferma, szpital i biuro porad, internat i przytułek noclegowy, sala koncertowa i tanie kuchnie oraz gmach nauki i sztuki, swą funkcją najbardziej zbliżony do tradycyjnej szkoły. Dzięki temu uczniowie mają możliwość zapoznania się z różnymi mikrośrodowiskami oraz sytuacjami życia społecznego, w których mogą ujawnić się ich predyspozycje i talenty. Traktowani są przy tym jak dorośli, podlegają tym samym co oni regułom życia społecznego, a wychowanie odbywa się przez pracę. Akcent nie jest zatem położony na nauczanie rozumiane jako transmisja wiedzy, ale na samowychowanie, a edukacja ma być ,wędrówką do pełnej samodzielności".

Najbardziej radykalnym rozwiązaniem zaproponowanym przez Korczaka jest odejście od ściśle określonych programów nauczania i preferowanych w nich przedmiotów, w tym języków starożytnych, na rzecz indywidualnego kształcenia się w tych dziedzinach, które okażą się przydatne do rozwijania zdolności poszczególnego ucznia i pomogą mu w pracy. Właśnie w twórczej, ale i fizycznej pracy, autor Dziecka salonu - podobnie jak Stanisław Brzozowski - widział najważniejsze spełnienie człowieka. Brzozowskiego można nazwać patronem filozoficznym tego projektu, nie tylko dlatego, że podkreślał aksjologiczną wartość pracy, podejmowanej bez przymusu, ale przede wszystkim dlatego, iż rozumiał 
ją jako wysiłek wzmagający potęgę jednostki i zbiorowości ${ }^{41}$. Najistotniejsze jest jednak to, że podstawową rolę działań edukacyjnych widział Korczak w kształtowaniu świadomości etycznej ucznia. Wychowanie miało przede wszystkim na celu podnoszenie kwalifikacji moralnych jednostki, a edukacja umożliwiająca harmonijny rozwój jednostek miała przyczynić się do przemiany społecznej. Odwołujący się do racjonalnych i pedagogicznie uzasadnionych przesłanek projekt reformatora-wychowawcy wyrastał z marzenia o innym, lepszym świecie. Powieść kończy się optymistycznie, mimo trudności placówka się rozwija, zdobywając uznanie w innych krajach. Być może takie zakończenie uznał Korczak za nadmiernie ideowe i życzeniowe zarazem, i dlatego nie opublikował tego utworu w postaci książkowej. A być może w swojej utopijnej wizji dostrzegł rys antyutopii, prowadzący do nadmiernej regulacji lub - a to przeciwny biegun - całkowitej anarchii w działaniach wychowawczych. Jedno i drugie zaprzeczałoby ideom nowoczesnej edukacji.

Zarysowane tutaj wątki rozważań, które da się odczytać z przywołanych utworów, składają się łącznie na antropologiczny wymiar zjawiska, jakim jest instytucjonalizowane nauczanie i określają problemy, przed którymi stało szkolnictwo przełomu XIX i XX wieku, czasu szybkich przekształceń społecznych i rozwoju cywilizacyjnego. Dla autora Syzyfowych prac szkoła to przede wszystkim instytucja podporządkowana zaborcy, pisarz odsłonił mechanizmy władzy-wiedzy ${ }^{42}$, które nastawione były na uczynienie z niej miejsca tożsamościowotwórczego, ale też pokazał mechanizmy neutralizowania takiego wpływu. Korczak nie podnosił kwestii rusyfikacji, dla niego stara, czyli funkcjonująca w czasach jemu współczesnych szkoła, czy to rosyjska, czy angielska skażona była prymatem treści politycznych, utrzymywała stary porządek, a u jej podstaw nie leżały pytania o dobro dziecka i dobro społeczne. Jednak przy całej różnicy zarówno jeśli idzie o poetykę, jaki sposób ujęcia tematu, obaj twórcy pokazali, że na progu nowoczesności u podłoża zinstytucjonalizowanych działań wychowawczych leżała myśl o przekształcaniu zbiorowości poprzez edukację jednostki. Ta idea determinowała kształt szkoły opresyjnej, poddającej ucznia ciągłemu nadzorowi, traktującej go jako obiekt edukacyjnych działań, ale też projekty liberalne, gdzie podstawowym założeniem było podmiotowe traktowanie ucznia, a celem działania pomoc dziecku w indywidualnym rozwoju i procesie samostanowienia. Jednocześnie literatura pokazywała, że w świecie panoptikum jednostki mogą odkrywać wartość wolności i nie poddawać się szkolnemu sterowaniu, a uto-

${ }^{41}$ Por. J. Gór ski, Aksjologia „Szkoły życia” Janusza Korczaka, http://lewicowo.pl/aksjologia-\%E2\%80\%9Eszkoly-zycia\%E2\%80\%9D-janusza-korczaka/ . Uważa się też, że pierwowzorem powieściowego Stacha, autora artykułu Praca jako czynnik wychowania oraz przyjaciela narratora, jest właśnie Stanisław Brzozowski. O „filozofii pracy” por. np. A. Wali ck i, Filozofia dojrzałości dziejowej [w:] S. B r zozow s ki, Idee, wstęp i oprac. A. Walicki, Kraków 1990, s. 40 i nast.

${ }^{42}$ Por. M. Fou c au lt, Nadzorować i karać, dz. cyt. 
pijne projekty przełamują się w antyutopię. W ten sposób odkrywała paradoksy zinstytucjonalizowanego nauczania, które stanowi przecież jedną z najbardziej powszechnych praktyk dnia codziennego w XX wieku.

\author{
Marta Rusek \\ LITERARY ANTHROPOLOGY OF THE SCHOOL OF THE LATE 19TH \\ AND EARLY 20TH CENTURY: A RECONNAISSANCE
}

Summary

This article attempts to point out the issues which make up the literary anthropology of the school of the late 19th and early 20th century. This period deserves special attention for a number of reasons, among them a rapid growth of the educational debate both in Europe and the United States and fundamental changes in the functioning of the educational system, eg. the extension of universal primary education, and the opening up of elementary and secondary schools for girls. All of those developments were not only associated with the idea of modernity but constituted the practical realization of the progressive content of that idea.

Our understanding of the anthropology of the school is based the premise that human beings acquire their knowledge (ie. learn and are taught) within an organized educational framework. The issues that this article deals with are directly connected with that institutional framework, ie. the school as an anthropological site, the technology of power, symbolic violence, individual subjectivity, the relationship between the individual and the group, individual and collective identity.

The discussion focuses on two books, which are characteristic of their time, Stefan Żeromski's popular school-novel The Labors of Sisyphus and Janusz Korczak's utopian novel The School of Life. They both suggest that the institutionalized educational drive of early modernity was aimed at influencing and transforming society through the schooling of individuals. What is striking about Żeromski's presentation of the school with its mechanism of knowledge as power, used by the Russian authorities to inculcate submission in individuals and in the society at large, is the sheer brazenness of the scheme which tends to neutralize its symbolic violence. By contrast, in Korczak's novel we find a totally new educational institution based on the principle of treating children as adults. For Korczak a radical respect for the autonomy of child and its individual development was the first step towards social change and the transformation of interpersonal relations. Our analyses demonstrate that fiction was used to examine the paradoxes inherent in institutionalized education at a time when it became one of the most universal forms of everyday praxis. 